\title{
Adenocarcinoma in the transposed colon: High grade active inflammation versus low grade chronic inflammation
}

\author{
Antonio V. Sterpetti*, Paolo Sapienza \\ University of Rome La Sapienza, Italy
}

\section{A R T I C L E I N F O}

\section{Article history:}

Received 3 May 2019

Accepted 12 May 2019

Available online $\mathrm{xxx}$

\section{Keywords:}

Colon cancer

Transposed colon

Inflammation

De novo cancer in transposed colon

\begin{abstract}
A B S T R A C T
Despite strong hereditary components, most cases of colorectal cancer are sporadic. The possibility to manipulate in the clinical setting the many presumed risk factors is almost impossible, and long-term epidemiological studies are the only reliable form for comparisons. We performed a systematic review to analyze the reports of de-novo adenocarcinoma arising in the transposed colon, used for conduit after esophagectomy, after total gastrectomy, and for vaginal reconstruction. In all these situations, the colon is transposed in different physiological conditions from its natural environment. We excluded patients in whom the colon was transposed as urinary conduit because the well known carcinogenic effect of the contact with urine. Overall 45 patients were identified with a de-novo adenocarcinoma arising in the transposed colon (36 after esophagectomy; 1 after total gastrectomy; 8 as neovagina). The only common risk factor in these different anatomic position was the possibility of active or chronic inflammation. There was not a close correlation between time after implantation and occurrence of the carcinoma. The occurrence of the de novo carcinoma was related to ageing, supporting the hypothesis of a major role of inflammation in facilitating deregulation of the immune system, associated with ageing.
\end{abstract}

(C) 2019 Published by Elsevier Ltd.
Despite strong hereditary components, most cases of colorectal cancer are sporadic. Epidemiological studies have shown a statistical correlation with cigarette smoking, alcohol abuse, red and processed meat high intake, obesity, reduced physical activity [1-3] Experimental and clinical research has been focused on several hypotheses: reduced colorectal transit time and consequent longer exposure of the mucosa to several proposed toxic agents; degradation products of substances at the basis of the daily diet; presence of specific bacteria in the colorectal flora. The possibility to manipulate in the clinical setting the many presumed risk factors is almost impossible, and long-term epidemiological studies are the only reliable form for comparisons [4].

The colon has been used to replace the esophagus and the stomach after esophagectomy and total gastrectomy. In vaginal reconstruction, for agenesis or after vaginectomy for cancer, the colon offers many advantages in comparison to other autologous tissues [5-7].

In all these situations, the colon is transposed in different physiological conditions from its natural environment. We

\footnotetext{
* Corresponding author. Viale del Policlinico, 00167, Rome, Italy.

E-mail address: antonio.sterpetti@uniroma1.it (A.V. Sterpetti).
}

performed a systematic review to analyze the reports of adenocarcinoma arising in the transposed colon. We excluded adenocarcinomata arising in the colon used as bladder substitute. The contact of the colonic mucosa with the urine has already been shown to be a significant risk factor for cancer occurrence. The primary outcome of this systematic review was to analyze the prevalence of the problem, and possible risk factors.

\section{Material and methods}

The methods used for the study and inclusion criteria were based on Preferred Reports Items for Systematic Reviews and Meta analyses (PRISMA) recommendations. A literature search was performed in June 2018 by two investigators who conducted a review of papers reported in PubMed, EMBASE, MEDLINE and Cochrane Database. The strings "COLON TRANSPLANT “, "ESOPHAGECTOMY”, "VAGINAL RECONSTRUCTION" "ADENOCARCINOMA IN TRANSPOSED COLON" were used in combination with the Boolean operators "and" "or". Editorials, letters to the Editor, Chapter in Books, Abstracts in Symposia, were included in the search. There was no language or time restriction and screened report. The registration number at International prospective register of systematic review (PROSPERO) was CRD 42018089691. 
Data Extraction: Data extraction was performed by two reviewers independently; a third reviewer was involved to solve any question in interpreting data. The third reviewer (ES) was never consulted. The primary outcome was to determine possible risk factors for adenocarcinoma in the transposed colon. Secondary outcomes were prevalence of the complication, stage at the time of diagnosis, therapy and clinical outcome.

Quality Assessment. Two independent reviewers determined the quality and risks of bias of analyzed studies by using the Newcastle-Ottawa scale [8]. This scale defines the quality of a paper with a score ranging from 0 to 9 . Papers with a score greater than 6 were considered of good quality.

Statistical Analysis. All primary outcomes were analyzed by the fixed-effects models. Student's $t$-test and X square test were used where appropriate.

\section{Results}

Literature Search: 6,650 papers published from June 1938 to December 2018, were identified. Two hundred five papers were fully evaluated, but only 45 papers clearly reported patients with a transposed colon autograft in which a de-novo adenocarcioma was diagnosed. We excluded the reports of patients in whom there was possibility that the carcinoma was already present at the time of transposition. The 45 included papers described single case reports of patients with a de-novo growth of an adenocarcinoma in the transposed colon; one patients had colon interposition after total gastrectomy for cancer, 36 patient had colon interposition after esophagectomy, 8 patients had reconstruction of the vagina with the colon Tables 1 and 2 describe the characteristics of the included studies.

The quality of the papers was good (average 7,5) with a detailed description of the clinical characteristics of the patients in all but 1 patient. The majority of the papers reported a short follow up (mean 8 months).

Clinical Characteristics of the Patients: Tables 1 and 2 show the clinical characteristics of the 45 patients. We were not able to identify any significant risk factor. Only two out of the 36 patients, in whom details were reported, abused of alcohol and cigarette smoking. Age ranged from 33 to 83 years (mean $63.9+-7$ years) and a synchronous adenocarcinoma in the native colon was evident in 3 patients (6.7\%). There was no evidence of familiarity for colorectal cancer or for inflammatory bowel disease.

Colon Transplant after Esophagectomy: In 36 patients a diagnosis of de novo carcinoma in the transposed colon was made. Age at the diagnosis ranged from 40 to 83 years $(65.6+-5)$. There were 22 males and 13 females (one report did not specify the gender of the patient). The histology was reported in 31 patients, and in all cases the adenocarcinoma was defined as moderately or highly differentiated. All patients had an elongated colon, with the possibility of delay empting and reflux in the colon of acid gastric content. In two patients a diagnosis of synchronous adenocarcinoma in the native, in-situ, colon was made (2/36: 5.5.\%). Two patients abused of tobacco smoking and alcohol. All patients had a regular, standard diet (presumably small and more frequent meals). No patient was reported as eating red meat. Details about their life style were available for 27 patients, who had a regular life style. None of the patients was obese. Time interval between the initial surgery and the diagnosis ranged from 1 to 55 years (mean 22.1+10 years) (Table 3 ). The clinical characteristics of these 36 patients were not different from those of patients among the general population with a diagnosis of colorectal cancer.

Colon Transplant for Vaginal Reconstruction. Age at the diagnosis ranged from 33 to 73 years (mean $54.1+-8$ years). Histology showed a highly secreting mucinous adenocarcinoma in all patients. Around the tumor there were evident signs of inflammation. Details of colonoscopy were reported in 6 patients: one had a synchronous mucinous adenocarcinoma, but in the other patients the colon did not show any abnormality and no signs of inflammation. Herpes virus was absent in all patients with vaginal reconstruction who developed adenocarcinoma. Among the 8 patients who had vaginal reconstruction, 4 patients (50\%) did not have any sexual intercourse. Adenocarcinoma developed at a mean of 28.5 year from neo-vagina reconstruction (range 3-53 years). The clinical characteristics of these 8 patients were not different from those of patients among the general population with a diagnosis of mucinous colorectal cancer.

Colon Transplant after Total Gastrectomy. One patient (Female, 68 years old) developed adenocarcinoma in the left colon transposed to re-establish intestinal continuity 9 years after total gastrectomy for cancer [9]. Histology showed a moderately differentiate adenocarcinoma, which was resected. Colonoscopy did not show abnormalities in the native colon rectum.

Prevalence of de-novo adenocarcinoma in the transposed colon The real prevalence of the problem is not identifiable from the literature data. The 45 patients were reported as "case reports". We reviewed the clinical outcomes of 23 reports which analyzed the long term clinical outcome of patients who had colon transposition for vaginal reconstruction [6,7,10] and after esophagectomy [11-20]. Overall 2900 patients were included in the review. (1000 patients had a follow up longer than 5 years and 450 a follow up longer than 10 years). None of the reviews of patients who vaginal reconstruction with the colon reported the occurrence of adenocarcinoma in the transposed colon. Two papers [12,13] reported a patient with occurrence of adenocarcinoma in a colon interposed after esophagectomy, with an incidence respectively of $1 / 271(0.5 \%)$ and $1 / 308(0.3 \%)$. One epidemiological study [19], which analyzed the 380 patients operated on for esophagectomy and colon interposition in England in the last 10 years, noted that 5 of the interviewed thoracic surgeons touched on the possibility of polyps in the transposed colon.

Preoperative Symptoms and Late Diagnosis: In 43 out of the 45 patients the diagnosis was made because of evident symptoms: dysphagia for patients who had colon transplant after esophagectomy and neo vagina bleeding for those who had colon neovagina reconstruction. At the time of diagnosis, the adenocarcinoma was at an advanced stage: 24 patients required resection; in 13 patients the disease had already metastasized, they only had radio-chemitoherapy with a very short life expectancy. Six patients had endoscopic removal of the tumor, but only two were asymptomatic. In two patients details about therapy were not available.

\section{Discussion}

Colon interposition after esophagectomy compares favorably to gastric pull-up as regard quality of life and alimentary satisfaction; however, it is a more difficult operation to be performed in dedicated centers. Adenocarcinoma arising in the colon conduit is considered a rare complication. The real prevalence of this complication is difficult to define. Tranchart et al. [13] reported a prevalence of about $0.5 \%$; however, considering that many of the patients had a follow-up shorter than 10 years, we can hypothesize a higher prevalence, approaching that of sporadic colorectal cancer in the general population, adjusted for age and sex. As esophageal substitute, the colon is exposed to an "un physiological" environment with different chemical and physical properties. Transit time is significantly longer for the reduced peristalsis in the interposed colon. The absence of the natural action of the lower sphincter, determines a significant reflux of gastric acid content in the interposed colon; these factors represent a conceptual basis for chronic 
Table 1

Cancer in the transposed colon after esophagectomy.

\begin{tabular}{|c|c|c|c|c|c|c|}
\hline Case report & Age/Sex & $\begin{array}{l}\text { Indication for } \\
\text { esophagectomy/Years } \\
\text { fromsurgery }\end{array}$ & Graft & Therapy & Diagnosis & AvailableFollow up \\
\hline Goldsmith et al., 1968 [21] & $51 / \mathbf{F}$ & $\begin{array}{l}\text { Squamous } \\
\text { Carcinoma/2 }\end{array}$ & Right colon & SegmentalResection & Squamouscell carcinoma & Alive and well 17 months \\
\hline Licata et al., 1978 [22] & $51 / \mathrm{M}$ & Corrosive/11 & Right colon & Supportivetherapy & Metastatic Adenocarcinoma & Early death \\
\hline Haerr et al., 1987 [23] & $72 / \mathrm{M}$ & $\begin{array}{l}\text { Squamous } \\
\text { Carcinoma/9 }\end{array}$ & Right colon & $\begin{array}{l}\text { Supportivetherapy } \\
\text { Chemotherapy }\end{array}$ & Locallyadvanced T4 & Died7 months \\
\hline Houghton et al., 1989 [24] & $64 / \mathrm{M}$ & Corrosive/20 & Right colon & $\begin{array}{l}\text { Colon Resestion and } \\
\text { Gastric pull-up }\end{array}$ & Localized Adenocarcinoma & $\begin{array}{l}1 \text { month } \\
\text { Alive and well }\end{array}$ \\
\hline Thiele et al.,1992 [25] & $55 / \mathrm{M}$ & Adenocarcinoma/12 & Left Colon & SegmentalResection & T3N2M0 & $\begin{array}{l}1 \text { month } \\
\text { Alive and well }\end{array}$ \\
\hline Lee et al., 1994 [26] & $75 / \mathrm{F}$ & $\begin{array}{l}\text { Squamous } \\
\text { Carcinoma/20 }\end{array}$ & Unkonown & $\begin{array}{l}\text { Colon Resection and jejunal } \\
\text { interposition }\end{array}$ & Localized Adenocarcinoma & $\begin{array}{l}1 \text { month } \\
\text { Alive and well }\end{array}$ \\
\hline Altorjay et al., 1995 [27] & $72 / \mathrm{M}$ & Corrosive/6 & Left colon & SegmentalResection & Adenocarcinoma & $\begin{array}{l}9 \text { years } \\
\text { Alive and well }\end{array}$ \\
\hline Jeyasingham et al1999 [12] & $? / ?$ & Corrosive/? & Left colon & $?$ & Adenocarcinoma & $?$ \\
\hline Kasaktin et al1999 [28] & $59 / \mathrm{M}$ & Corrosive/8 & Right Colon & SegmentalResection & Adenocarcinoma & $\begin{array}{l}18 \text { months } \\
\text { Alive and well }\end{array}$ \\
\hline Goyal et al2000 [29] & $78 / \mathrm{M}$ & Adenocarcinoma/7 & Left Colon & SegmentalResesction & $\begin{array}{l}\text { Locallyadvanced } \\
\text { T3NOM0 }\end{array}$ & Died 13 months. \\
\hline Mukai et al2001 [30] & $? / \mathrm{M}$ & $\begin{array}{l}\text { Squamous } \\
\text { carcinoma/6 }\end{array}$ & Left colon & EndoscopicResection & Localizedcancer & 12 monthsAlive and well \\
\hline Liau et al2004 [31] & $79 / M$ & $\begin{array}{l}\text { Squamous } \\
\text { Carcinoma/30 }\end{array}$ & Unknown & Chemotherapy & Metastatic adenocarcinoma & Died 4 months \\
\hline Martìn et al., 2005 [32] & $65 / \mathrm{F}$ & Corrosive/40 & Right colon & SegmetalResection & Dukes B Adenocarcinoma & 1 monthAlive and well \\
\hline Hsieh et al., $2005 *$ [33] & $57 / \mathrm{M}$ & Corrosive/39 & Right colon & SegmentalResesction & LocalizedAdenocarcinoma & $\begin{array}{l}1 \text { month } \\
\text { Alive and well }\end{array}$ \\
\hline Hwang et al., 2007* [34] & $60 / \mathrm{F}$ & Corrosive/40 & Notspecified & EndoscpicResection & Intramucosal Adenocarcinoma & $\begin{array}{l}1 \text { month } \\
\text { Alive and well }\end{array}$ \\
\hline $\begin{array}{l}\text { Roos et al. } \\
2007 \text { [35] }\end{array}$ & $72 / \mathrm{M}$ & Adenocarcinoma/7 & Right colon & SegmentalResesction & LocalizedCancer & 1 monthAlive and well \\
\hline Kia et al., 2010 [36] & $76 / \mathrm{M}$ & Adenocarcinoma/15 & Unknown & EndoscopicResection & Localized adenocarcinoma & $\begin{array}{l}1 \text { month } \\
\text { Alive and well }\end{array}$ \\
\hline Sikorszki et al., 2010 [37] & $75 / \mathrm{M}$ & Corrsoive/44 & Right colon & SegmentalResesction & Adenocarcinoma & Notspecified \\
\hline Bando et al2010 [38] & $80 / \mathrm{M}$ & $\begin{array}{l}\text { Squamous } \\
\text { carcinoma/14 }\end{array}$ & Unknown & EndoscopicResection & Localized adenocarcinoma & 1 monthAlive and well \\
\hline Shersher et al., 2011 [39] & $60 / \mathrm{M}$ & Corrosive/40 & Notspecified & $\begin{array}{l}\text { Colon resection and } \\
\text { esophagogastroplasty }\end{array}$ & T1 N0 Adenocarcinoma & $\begin{array}{l}3 \text { months } \\
\text { Alive and well }\end{array}$ \\
\hline Spitali et al., 2012 [40] & $66 / \mathrm{M}$ & Adenocarcinoma/2 & Right colon & SegmentalResection & Localized adenocarcinoma & 24 monthsAlive and well \\
\hline Suzumura et al., 2012 [41] & $72 / \mathrm{M}$ & $\begin{array}{l}\text { Squamous } \\
\text { carcinoma/1 }\end{array}$ & Right colon & SegmentalResection & Localized adenocarcinoma & 36 monthsAlive and well \\
\hline Kim et al., 2012 [42] & $70 / \mathrm{F}$ & Corrosive/47 & Right Colon & Chemotherapy & $\begin{array}{l}\text { Metastatic } \\
\text { Adenocarcinoma }\end{array}$ & Died 6 months \\
\hline Wang et al., 2012 [43] & $41 / \mathrm{F}$ & Corrosive/15 & Unknown & Chemotherapy & Metastatic Adenocarcinoma & Died 4 mopnths \\
\hline Aryal et al., 2013 [44] & $60 / \mathrm{M}$ & Corrosive/30 & Right Colon & Supportive & Metastatic Adenocarcinoma & Early Death \\
\hline Grunner et al., 2013 [45] & $59 / \mathrm{F}$ & Corrosive/55 & Transverse colon & SegmentalResection & Localized adenocarcinoma & Alive and well 6 months \\
\hline Sallum et al., 2014 [46] & $53 / \mathrm{F}$ & Atresia/42 & Unknown & $\begin{array}{l}\text { Colon resection and } \\
\text { gastric pull-up }\end{array}$ & $\begin{array}{l}\text { Locally Invasive } \\
\text { Adenocarcinoma }\end{array}$ & $\begin{array}{l}\text { Died after } 9 \text { months for } \\
\text { surgery-related } \\
\text { complications. }\end{array}$ \\
\hline Tranchart et al., 2014 [13] & $66 / \mathrm{M}$ & Corrosive/19 & Right Colon & Chemotherapy & Metastatic Adenocarcinoma & Died3months \\
\hline $\begin{array}{l}\text { Ng et al. } \\
2014 \text { [47] }\end{array}$ & $60 / \mathrm{M}$ & Corrosive/19 & Unknown & $\begin{array}{l}\text { Supportive } \\
\text { Metastaticlungcancer }\end{array}$ & Severe dysplasia & Earlydeath \\
\hline Cheng et al., 2015 [48] & $40 / \mathrm{F}$ & Corrosive/15 & Right Colon & Supportive & Metastatic Adenocarcinoma & Died4months \\
\hline Yamamoto et al., 2015 [49] & $83 / \mathrm{M}$ & Carcinoma/? & Left Colon & SegmentalResection & T2N1M0 & $\begin{array}{l}24 \text { months. Alive. } \\
\text { Lymph node recurrence }\end{array}$ \\
\hline $\begin{array}{l}\text { Kroner et al. } \\
2015 \text { [50] }\end{array}$ & $67 / \mathrm{M}$ & Carcinoma/10 & Left Colon & $\begin{array}{l}\text { Supportive } \\
\text { Endoscopicstenting }\end{array}$ & Metastaticadenocarcinaoma & Unknown \\
\hline Taslimi et al., 2017 [51] & $84 / \mathrm{F}$ & Unknown/34 & Unknown & Supportive & $\begin{array}{l}\text { Carcinoma } \\
\text { Colo-tracheal fistula }\end{array}$ & Earlydeath \\
\hline De Moura et al., 2018 [52] & $63 / \mathrm{F}$ & Corrosive/8 & Unknown & Supportive & Metastatic Adenocarcinoma & Died 2 months \\
\hline Barbosa et al., 2018 [53] & $70 / \mathrm{F}$ & Corrosive/19 & Left Colon & Supportive & Poor General Conditions & Died 6 months \\
\hline Iascone et al., 2019 [54] & $67 / F$ & Corrosive/37 & Left Colon & EndoscopicResection & Localizeddisease & 60 months. Alive and well \\
\hline
\end{tabular}

inflammation [63,64]. At the same time, exposure to acid reflux reduces the possibility of bacteria overgrowth in the colon. The new location of the transposed colon, prevents the action of toxins, derived from degradation of ingested substances, like red meat, which have been correlated to cancer formation and progression. None of the reported patients were obese, and only few abused of alcohol and tobacco. The clinical conditions of the patients, and the new position of the colon, did not allow the action of several factors, generally considered as major risk for cancer occurrence. The cancers arising in the interposed colon had clinical and histological characteristics similar to those of sporadic adenocarcinomata occurring in the general population. Other similar clinical characteristics between the adenocarcinoma arising in the colon conduit and the sporadic carcinoma in the general population included the age of the patients and the synchronous occurrence of a cancer in the native colon in $5.6 \%$ of the patients. Despite 
Table 2

Cancer in the transposed colon as neovagina.

\begin{tabular}{|c|c|c|c|c|c|}
\hline Author & Age & Indication to Colon Neovagina/Years from Surgery & Graft & Therapy & Available Follow-up \\
\hline LavandHomme (1938) [55] & 33 & Agenesy/20 & Sigmoid & Radiation & Not specified \\
\hline Andryjowicz et al. (1985) [56] & 43 & Malignancy $/ 4$ & Cecum & Resection & Not specified \\
\hline Ursic-VrscaJ et al. (1994) [57] & 58 & Malignancy/22 & Sigmoid & Resection & 30 months Alive and well \\
\hline Hiroi et al. (2001) [58] & 53 & Agenesy/25 & Sigmoid & Resection & 18 months Alive and well \\
\hline Van der Velden et*(2005)m [59] & 45 & Malignancy/17 & Sigmoid & Resection & 16 months Alive Liver mets \\
\hline Kita et al. (2015) [60] & 67 & Agenesy/40 & Sigmoid & Resection & 6 moths Alive and well \\
\hline Bogliolo et al. (2015) [61] & 61 & Agenesy/48 & Sigmoid & Resection & 12 months. Alive and well \\
\hline Yamada et al. (2018) [62] & 73 & Agenesy/53 & Sigmoid & Resection & 2 months. Alive and well \\
\hline
\end{tabular}

*Synchronous cancer in the native colon.

Table 3

Time-interval between initial surgery of colon transposition and the diagnosis of a de novo carcinoma.

\begin{tabular}{|c|c|c|c|}
\hline Time interval & NEOVAGINA [8] & POST- ESOPHAGECTOMY(35) & POST-GASTRECTOMY(1) \\
\hline $1-10$ years & 1 & 9 & 1 \\
\hline $11-20$ years & 2 & 12 & \\
\hline $21-30$ years & 2 & 4 & \\
\hline More than 30 years & 3 & 10 & \\
\hline
\end{tabular}

significant environmental differences, in 2 patients, the adenocarcinoma occurred simultaneously in the native and transposed colon, with similar histologic characteristics.

In the 8 patients, in whom the adenocarcinoma arose in the colon transposed for vaginal reconstruction, there was evidence of active inflammation. Histologically, the adenocarcinoma was mucinous adenocarcinoma, surrounded by acute inflammation. The risk factors for sporadic colonic cancer in the general population, or for intrathoracic transposed colon after esophagectomy (passage of food, reduced transit time, gastric reflux) were not present. The only probable risk factor was related to bacterial overgrowth, infection and consequent active inflammation. In these 8 patients the clinical and histological characteristics were similar to those of patients with colon cancer and inflammatory bowel disease, including an earlier diagnosis in comparisons to sporadic cancers.

The time elapsed between the transposition of the colon and the diagnosis of adenocarcinoma varied significantly. However, the age at the diagnosis was similar to that of the general population, adjusted for age and sex: the mean age and histological characteristics of patients with cancer arising in the transposed colon after esophagectomy, with probable chronic inflammation, were similar to those of patients with sporadic colon cancer in the general population; whereas, the mean age and histological characteristics of the 8 patients with cancer arising in the context of severe, active inflammation in the transposed colon for vaginal reconstruction, were similar to those of patients with inflammatory bowel disease and colon cancer.

These data suggest the hypothesis of an age-related genetic predisposition. This genetic predisposition seems to be correlated to the presence of local inflammation. The several risk factors identified in patients with sporadic colon cancer, as well as in de novo carcinoma arising in the transposed colon, have a common final action represented by chronic or acute inflammation and possible damage to the colonic mucosa [65-68].

Ageing is undeniably one of the most powerful determinants of the development of cancer. However, what drives development of cancer with ageing, beyond the obvious prolonged exposure to traditional risk factors, is unclear $[69,70]$.

In patients with familial colorectal cancer, like Lynch syndrome, the genetic mutation MSI/MMR is present in more than $90 \%$ of the patients. In patients with sporadic colorectal cancer a genetic mutation is evident in less than $6 \%$ of the patients, and several different genetic mutations have been identified, some with high penetrance, other with low penetrance. Thus, there is not a common genetic finding in sporadic colorectal cancer $[65,66]$ On the other hand, patients with sporadic colorectal cancer present many similar clinical characteristics, which bring to hypothesize a possible common causal background.

Deregulation of the immune system with ageing is a well know phenomenon [71,72].

The basic influence of immunity in colorectal cancer progression, the close correlation of sporadic colorectal cancer with ageing, and the derangement of the immune response with ageing [72] determine a conceptual cause-effect relationship between potential factors which could influence the ageing-dependent deregulation of the immune system and sporadic colorectal cancer occurrence. Inflammation in genetically predisposed patients may promote somatic changes in hematopoietic cell lines promoting cancer occurrence [71]. Thus, inflammation might determine a double action, local and systemic. The hypothesis that the stimuli related to a long term inflammation might determine a general derangement in the hematopoietic system, can explain the occurrence of other types of cancer in the elderly. Inflammation may be a driver for ageing per se and for ageing consequences [73,74]. Interesting enough, in 3 patients, the cancer occurred synchronously in the transposed colon and in the native colon, with similar histological characteristics despite the differences in the two anatomic positions. These synchronous cancers could be related to a local genetic-determined cause; we cannot exclude the possibility of a general genetic-determined derangement of the immune system.

Several other considerations should be advanced. In all patients there was a tardive diagnosis which brought to poor clinical outcomes. Early diagnosis was erratic and followed by good results. Even if practical guidelines are difficult to be drawn on the basis of the few number of patients analyzed, it is wise to assert that colonoscopy screening as suggested by the American Gastroenterology Society should be applied to these patients, starting at the age of 35-40 years.

\section{Funding}

No funds were received for this work. 


\section{Conflicts of interest to disclose}

None.

\section{Aknowledgement}

We are grateful to Dr Enrica Salone for her support.

\section{References}

[1] Siegel RL, Miller KD, Jemal. A cancer statistics, 2018. CA cancer J Clin 2018;68: 7-30.

[2] White A, Joseph D, Rim SH, Johnson CJ, Coleman MP, Allemani C. Colon cance survival in the United States by race and stage (2001-2009): findings from the CONCORD-2 study. Cancer 2017;123(Suppl 24):5014-36. https://doi.org/ $10.1002 /$ cncr.31076.

[3] Allemani C, Matsuda T, Di Carlo V Harewood R, Matz M, Nikšić M, Bonaventure A, et al. IGlobal surveillance of trends in cancer survival 2000-14 (CONCORD-3): analysis of individual records for 37513025 patients diagnosed with one of 18 cancers from 322 population-based registries in 71 countries. Lancet 2018;391:1023-75. https://doi.org/10.1016/S01406736(17)33326-3.

[4] Fiori E, Lamazza A, Demasi E, Sterpetti AV, DeToma G l. Association of liver steatosis with colorectal cancer and adenoma in patients with metabolic syndrome. Anticancer Res 2015;35:2211-4.

[5] DeMeester TR, Kauer WKH. Esophageal Reconstruction: the colon as an esophageal substitute. Dis Esophagus 1995;8:20-9.

[6] Parsons JK, Gearhart SL, Gearhart JP. Vaginal reconstruction utilizing sigmoid colon: complications and long-term results. J Pediatr Surg 2002;37:629-33.

[7] Hensle TW, Reiley EA. Vaginal replacement in children and young adults. J Urol 1998;159:1035-8.

[8] Cochrane handbook for systematic reviews of interventions. In: Higgins JPT Green S, editors. Section 13.5.2.3. Tools for assessing methodological quality or risk of bias in non-randomized studies. London: The Cochrane Collaboration; 2011. Version 5.1.0.

[9] Kuwabara Y1, Kimura M, Mitsui A, Ishiguro H, Tomoda K, Mori Y, et al. Adenocarcinoma arising in a colonic interposition following a total gastrec tomy: report of a case. Surg Today 2009;39:800-2. https://doi.org/10.1007/ s00595-008-3932-2.

[10] Martinez-Mora J, Isnard R, Castellvi A, López Ortiz P. Neovagina in vagina agenesis: surgical methods and long-term results. J Pediatr Surg 1992;27: $10-4$.

[11] Greene CL, DeMeester SR, Augustin F, Worrell SG, Oh DS, Hagen JA, DeMeester TR. Long-term quality of life and alimentary satisfaction after esophagectomy with colon interposition. Ann Thorac Surg 2014;98:1713-9.

[12] Jeyasingham K, Lerut T, Belsey RH. Functional and mechanical sequelae of colon interposition for benign oesophageal disease. Jeyasingham $\mathrm{K}$, Lerut $\mathrm{T}$, Belsey RH. Eur J Cardiothorac Surg 1999;15:327-31.

[13] Tranchart H, Chirica M, Munoz-Bongrand N, Sarfati E, Cattan P. Adenocarcinoma on colon interposition for corrosive esophageal injury: case report and review of literature. J Gastrointest Cancer 2014;45(Suppl. 01):205-7.

[14] Renzulli P, Joeris A, Strobel O, Hilt A, Maurer CA, Uhl W, et al. Colon interposition for esophageal replacement: a single-center experience. Langenbeck's Arch Surg 2004;389:128-33.

[15] Yildirim S, Köksal H, Celayir F, Erdem L, Oner M, Baykan A. Colonic interposition vs. gastric pull-up after total esophagectomy. J Gastrointest Surg 2004 Sep-Oct;8(6):675-8.

[16] Knezević JD, Radovanović NS, Simić AP, Kotarac MM, Skrobic OM, Konstantinovic VD, et al. Colon interposition in the treatment of esophageal caustic strictures: 40 years of experience. Dis Esophagus 2007;20:530-4.

[17] Davis PA, Law S, Wong J. Colonic interposition after esophagectomy for cancer. Arch Surg 2003;138:303-8.

[18] Mine S, Udagawa H, Tsutsumi K, Kinoshita Y, Ueno M, Ehara K, et al. Colon interposition after esophagectomy with extended lymphadenectomy for esophageal cancer. Ann Thorac Surg 2009;88:1647-53. https://doi.org/ 10.1016/j.athoracsur.2009.05.081.

[19] Fisher RA, Griffiths EA, Evison F, Mason RC, Zylstra J, Davies AR, et al. A national audit of colonic interposition for esophageal replacement. Dis Esophagus 2017;30:1-10. https://doi.org/10.1093/dote/dow003.

[20] Brown J, Lewis WG, Foliaki A. Colonic interposition after adult oesophagectomy: systematic review and meta-analysis of conduit choice and outcome J Gastrointest Surg 2018;22:1104-11. https://doi.org/10.1007/s11605-0183735-8.

[21] Goldsmith HS, Beattie EJJ. Malignant villous tumor in a colon bypass. Ann Surg 1968; $167: 98-100$.

[22] Licata AA, Fecanin P, Glowitz R. Metastatic adenocarcinoma from oesophageal colonic interposition. Lancet 1978;1:285.

[23] Haerr RW, Higgins EM, Seymore CH. Adenocarcinoma arising in a colonic interposition following resection of squamous cell esophageal cancer. Cancer 1987;60:2304-7.

[24] Houghton AD, Jourdan M, McColl I. Dukes A carcinoma after colonic interposition for oesophageal stricture. Gut 1989;30:880-1.
[25] Theile DE, Smithers BM, Strong R, Windsor CJ. Primary adenocarcinoma in a colonic „oesophageal“ segment. Aust N Z J Surg 1992;62:158-60.

[26] Lee SJ, Koay CB, Thompson H, Nicolaides AR, Das Gupta AR. Adenocarcinoma arising in an oesophageal colonic interposition graft. J Laryngol Otol 1994;108:80-3.

[27] Altorjay A, Kiss J, Voros A, Szanto I, Bohak A. Malignant tumor developed in colon-esophagus. Hepato-Gastroenterology 1995;42:797-9.

[28] Kasatkin VF, Kit OI, Fomenko IA. Cancer of the artificial esophagus fifty years after prethoracic plasty (Russian)Vestn Khir Im I I Grek 2012:171:82-3.

[29] Goyal M, Bang DH, Cohen LE. Adenocarcinoma arising in interposed colon: report of a case. Dis Colon Rectum 2000;43:555-8.

[30] Mukai M, Makuuchi K, Mukohyama S, Oida J, Himeno S, Nishi T, et al. Satoh S Quintuple carcinomas with metachronous triple cancer of the esophagus, kidney, and colonic conduit following synchronous double cancer of the stomach and duodenum. Oncol Rep 2001;8:111-4.

[31] Liau CT, Hsueh S, Yeow KM. Primary adenocarcinoma arising in esophageal colon interposition: report of a case. Hepato-Gastroenterology 2004;51: 748-9.

[32] Martin MA, Ferras A. Colon cancer: a rare complication in a colonic esophageal segment after coloesophagoplasty. (Spanish). Cir Esp 2005;77:46-7.

[33] Hsieh Y-S, Huang K-M. Cheng Metachronous adenocarcinoma occurring at an esophageal colon graft. J Formos Med Assoc 2005;104:436-40.

[34] Hwang HJ, Song KH. Youn YH A case of more abundant and dysplastic adenomas in the interposed colon than in the native colon. Yonsei Med J 2007;48: 1075-8.

[35] Roos D, Busch ORC, van Lanschot JJB. Primary colon carcinoma in a colon interposition graft after oesophageal resection (Netherlands) Ned Tijdschr. Gene 2007; 151:2111-4

[36] Kia L, Sikka SK, Komanduri S. An unusual case of malignant dysphagia after colonic interposition treated with endoscopic mucosal dissection. Gastrointest Endosc 2010;72:1320-1.

[37] Sikorszki L, Horvath OP, Papp A. Colon cancer after colon interposition for oesophageal replacement. (Hungarian). Magy Sebeszet 2010;63:157-60.

[38] Bando H, Ikematsu H, Fu K-I, Oono Y, Kojima T, Minashi K, et al. A laterallyspreading tumor in a colonic interposition treated by endoscopic submucosal dissection. World J Gastroenterol 2010;16:392-4.

[39] Shersher DD, Hong E, Warren W, Penfield Faber L, Liptay MJ. Adenocarcinoma in a 40-year-old colonic interposition treated with Ivor Lewis esophagectomy and esophagogastric anastomosis. Ann Thorac Surg 2011;92:e113-4.

[40] Spitali C, De Vogelaere K, Delvaux G. Dysphagia after colon interposition graft for esophageal carcinoma. Case Rep Pathol 2012;2012:738205. https:// doi.org/10.1155/2012/738205.

[41] Suzumura K, Oh K, Kuroda N. Primary adenocarcinoma arising in an interposed colon. Esophagus 2013;10. https://doi.org/10.1007/s10388-0120351-7.

[42] Kim ES, Park KS, Cho KB, Kim MJ. Adenocarcinoma occurring at the interposed colon graft for treatment for benign oesphageal stricture. Dis Esophagus 2012:25:175.

[43] Wang HB, Perng WC, Wang YC, Chen CW. Adenocarcinoma arising in colonic interposition with endobronchial metastasis. QJM 2012;105(3):273-5. https://doi.org/10.1093/qjmed/hcr033.

[44] Aryal MR, Mainali NR, Jalota L, Altomare JF. Advanced adenocarcinoma in a colonic interposition segment. BMJ Case Rep 2013. https://doi.org/10.1136/ bcr-2013-009749.

[45] Grunner S, Gilshtein H, Kakiashvili E, Kluger Y. Adenocarcinoma in colonic interposition. Case Rep Oncol 2013;6:186-8.

[46] Sallum RAA, Fonseca GM, Szachnowicz S, Seguro FCBDC, Cecconello I. Adenocarcinoma of transposed colon: first case of synchronous tumor. Arq Bras Cir Dig 2014;27:163-4.

[47] Ng DW, Ching Tan GW, Ching Teo MC. Malignancy arisingin a 41-year-old colonic interposition graft. Asian J Surg;39:45-47.

[48] Cheng YC, Wu CC, Lee CC. Adenocarcinoma of a colonic interposition graft for benign esophageal stricture in a young woman. Endoscopy 2015;47(Suppl. 01):E249-50.

[49] Yamamoto M, Yamasaki M, Sakai D. A case of colon cancer that developed in the subcutaneously reconstructed colon after esophagectomy for thoracic esophageal cancer. Gan To Kagaku Ryoho 2015;42:2230-2.

[50] Kröner PT, Mönkemüller K. Dual esophageal and colon self-expanding metal stenting for colon cancer arising in esophagealinterposition. Endoscopy 2015;47(Suppl 1 UCTN):E221-2. https://doi.org/10.1055/s-0034-1391830.

[51] Taslimi R, Jowkar A, Hasani Ghavam MR, Tavasol T, Allameh SF, Rakhshani N. Squamous cell carcinoma (SCC) arising in esophageal colon interposition. Oxf Med Case Rep 2017 Dec 18;2017(12):omx068. https://doi.org/10.1093/omcr/ omx068. eCollection 2017 Dec.

[52] De Moura DTH, Ribeiro IB, Coronel M, De Moura ETH, Carvalho JR, Baba ER, et al. Primary adenocarcinoma arising in esophageal colon interposition for corrosive esophageal injury: a case report and review of the literature. Endosc Int Open 2018;06:E1406-9.

[53] Barbosa B, Santos B, Mesquita I, Marcos M, Nogueira C. Santos J Adenocarcinoma arising in a colonic interposition after esophagectomy for benign stricture and review of the literature. J Surg Case Rep 2018;2018(10):rjy264. https://doi.org/10.1093/jscr/rjy264.

[54] Iascone C, Urbani L, Cavicchi F, Mascioli F, Sorrentino M, Pronio A, Sterpetti AV adenocarcinoma in the intrathoracic transposed colon.Ann Thorac Surg. . doi: 10.1016/j.athoracsur.2019.01.081. 
[55] Lavand Homme P. Complication tardive apparue au niveau de un vagin artificiel. Brux Med 1938:19:14-5.

[56] Andryjowicz E, Qizilbash AH, DePetrillo AD, O'Connell GJ, Taylor MH. Adenocarcinoma in a cecal neovagina-complication of irradiation: report of a case and review of literature. Gynecol Oncol 1985;21:235-9. https://doi.org/ 10.1016/0090-8258(85)90258.

[57] Ursic-Vrscaj M, Lindtner J, Lamovec J, Novak J. Adenocarcinoma in a sigmoid neovagina 22 years after Wertheim-Meigs operation. Case report. Eur J Gynaecol Oncol 1994:15:24-8.

[58] Hiroi H, Yasugi T, Matsumoto K, Fujii T, Watanabe T, Yoshikawa H, et al Mucinous adenocarcinoma arising in a neovagina using the sigmoid colon thirty years after operation: a case report. J Surg Oncol 2001;77:61-4. https:// doi.org/10.1002/jso.106.

[59] van der Velden AP, de Hingh IH, Schijf CP, Bonenkamp HJ, Wobbes T. Metachronous colorectal malignancies: “don't forget the neo vagina". A case report. Gynecol Oncol 2005;97:279-81. https://doi.org/10.1016/j.ygyno.2004.12.025.

[60] Kita Y, Mori S, Baba K, Uchikado Y, Arigami T, Idesako T, et al. Mucinous adenocarcinoma emerging in sigmoid colon neovagina 40 years after its creation: a case report. World J Surg Oncol 2015;13:213. https://doi.org 10.1186/s12957-015-0636-0.

[61] Bogliolo S, Gaggero CR, Nadalini C, Iacobone AD, Musacchi V, Cassani C, et al. Long-term risk of malignancy in the neovagina created using colon graft in vaginal agenesis-a case report. J Obstet Gynaecol 2015;35:543-4. https:// doi.org/10.3109/01443615.2014.987112.

[62] Yamada K, Shida D, Kato T, Yoshida H, Yoshinaga S, Kanemitsu Y. Adenocarcinoma arising in sigmoid colon neovagina 53 years after construction. World J Surg Oncol 2018 Apr 27;16(1):88. https://doi.org/10.1186/s12957-0181372-z.

[63] Isolauri J, Helin H, Markulla H. Colon interposition for esophageal disease: histologic finding of colonic mucosa after a follow-up of 5 months to 15 years. Am J Gastroenterol 1991;86:277-80.

[64] Elshafei H, Elshafei E, ElDebeiky M, Hegazy N, Zaki A, Abdel Hay S. Colonic conduit for esophageal replacement: long-term endoscopic and histopathologic changes in colonic mucosa. J Pediatr Surg 2012;47:1658-61. https:// doi.org/10.1016/j.jpedsurg.2012.04.002.

[65] Mantovani A, Allavena P, Sica A. Cancer related inflammation. Nature $2008 ; 454: 436-44$.

[66] Mantovani A, Cassatella MA, Costantini C. Neutrophils in the activation and regulation of innateand adaptive immunity. Nat Rev Immunol 2011;11: 519-31.

[67] Grivennikov SI, Greten FR, Karin M. Immunity, inflammation, and cancer. Cell 2010;140:883-99.

[68] Candido J, Hagemann T. Cancer-related inflammation. J Clin Immuno 2013;1(33Suppl):S79-84.

[69] Libby P, Kobold S. Inflammation: a common contributor to cancer, aging, and cardiovascular diseases-expanding the concept of cardio-oncology. Cardiovasc Res 2019;115:824-9. https://doi.org/10.1093/cvr/cvz05.

[70] Galdiero MR, Marone G, Mantovani A. Cancer inflammation and cytokines. Cold Spring Harb Perspect Biol 2018;10. https://doi.org/10.1101/cshperspect. a028662.

[71] Jaiswal S, Fontanillas P, Flannick J, Manning A, Grauman PV, Mar BG, et al. Agerelated clonal hematopoiesis associated with adverse outcomes. N Engl J Med 2014;371:2488-98.

[72] Gabrilovich DI, Ostrand-Rosenberg S, Bronte V. Coordinated regulation of myeloid cells by tumours. Nat Rev Immunol 2012;12:253-68.

[73] Rothwell PM, Cook NR, Graziano JM, Price JF, Belch JFF, Roncaglioni MC, et al. Effects of aspirin on risks of vascular events and cancer according to bodyweight and dose: analysis of individual patient data from randomised trials. Lancet 2018;392:387-99.

[74] Samadder NJ, Kuwada SK, Boucher KM, Byrne K, Kanth P, Samowitz W, et al. Association of sulindac and erlotinib vs placebo with colorectal neoplasia in familial adenomatous polyposis: secondary analysis of a randomized clinical trial. JAMA Oncol 2018;4:671-678doi. https://doi.org/10.1001/jamaoncol. 2017.5431. 